\title{
Resiliency and social support as factors promoting the process of resilience in adolescents - wards of children's homes
}

\begin{abstract}
BACKGROUND
The aim of the study was to investigate whether in a group of adolescents - wards of children's homes - the process of resilience occurs and to determine the role of resiliency (understood as a personality trait) and social support in this process. At least an average level of sense of quality of life was an indicator of resilience.
\end{abstract}

PARTICIPANTS AND PROCEDURE

Results of 60 adolescents were analyzed, among them 29 boys and 31 girls, aged $11-17$ years $(M=14.80, S D=2.00)$. The Subjective Quality of Life Questionnaire for Children and Adolescents, the Resiliency Assessment Scale, and the Social Support Questionnaire were used in the study.

\section{RESULTS}

Fifty-one and sixty one-hundredths percent of participants revealed at least an average level of sense of quality of life.

\begin{abstract}
Higher levels of resiliency and social support were found in subjects with a higher level of sense of quality of life. Resiliency and social support were found to be predictors of sense of quality of life in the examined group of adolescents, but resiliency has greater predictive power. Among resiliency factors, optimistic attitude and energy play the essential role in predicting sense of quality of life, and among the types of social support, information support is most important.
\end{abstract}

\section{CONCLUSIONS}

The results indicate that personal resources play a more important role in occurrence of the process of resilience than social resources.

\section{KEY WORDS}

quality of life; social support; resiliency; wards of children's homes

organizations - Institute of Psychology, University of Lodz, Lodz, Poland

aUthors' Contribution - A: Study design - B: Data collection - C: Statistical analysis - D: Data interpretation .

E: Manuscript preparation · F: Literature search · G: Funds collection

CORResPonding AUthor - Prof. Nina Ogińska-Bulik, Institute of Psychology, University of Lodz, 10/12 Smugowa Str., 91-433 Lodz, Poland, e-mail: noginska@uni.lodz.pl

TO CITE THIS ARTICLE - Ogińska-Bulik, N., \& Kobylarczyk, M. (2015). Resilience and social support as factors promoting the process of resilience in adolescents - wards of children's homes. Health Psychology Report, 3(3), 210-219.

DOI: $10.5114 /$ hpr.2015.49045 


\section{BACKGROUND}

\section{THE TERM RESILIENCE}

In recent years, resilience has been a subject of great interest to both researchers and practitioners. The term has been borrowed from physics, where it means returning to the previous state after a temporary deformation. It can be understood either as a process related to immunity or hardiness, or as an individual's personality trait.

Resilience, understood as a process, is associated with the functioning of children and youth in emergency situations, and it refers to good adaptation of the individual despite the exposure to stressful situations and adversities. Masten and Coatsworth (1995, p. 737) state that resilience means "achieving desirable outcomes in spite of significant challenges to adaptation".

Luthar, Cicchetti, and Becker (2000) have a similar understanding of the phenomenon. They relate resilience to the process of dynamic, positive adaptation in the face of emerging adversities. They also stress that the activation of this process requires experiencing an immediate threat or a traumatising situation. Resilience manifests itself in the preservation of the skills and competences allowing the individual to deal with such adversities.

Among Polish authors, Borucka and Ostaszewski (2008) as well as Junik (2011), for example, also present the understanding of resilience as a process. According to Ostaszewski (2005), resilience is a "multi-factor process of positive adaptation, in which the protective factors compensate for, or reduce the influence of risk factors" (p. 2). Certain life events, such as death of a parent, parents' divorce, illness (including that of a close family member), poverty, parents' alcoholism, or a complicated history of familial factors are commonly listed among risk factors (Ferguson \& Horwood, 2003; Grzegorzewska, 2013a; Ostaszewski, 2005). However, it is stressed that the resilience process - normal development of a child despite experiencing adversities - is most of all an effect of one's competences in dealing with these adversities, including personal skills and a favourable influence of external factors. Therefore resilience can be described as finding a balance between the risk and protective factors. According to the model proposed by Haase and colleagues (in: Ahern, Kiehl, Lou Sole, \& Byers, 2006), the process of resilience in children involves three categories of factors: individual protective factors, family protective factors and social protective factors.

A wide repertoire of individual skills and personal resources aids the process of resilience. These include good relations with peers, high intelligence (both cognitive and emotional), sense of humour, as well as the ability to solve problems, especially in emergency situations. Low levels of aggression, the ability to cooperate with others, and the sense of one's ability to control their environment play a role as well (Garmezy, 1991). Other authors (e.g. Masten \& Obradovic, 2008) also include high levels of extroversion and diligence, gentle disposition, self-esteem and the sense of self-efficacy.

Family and local environment play an important role among the environmental factors. Winfield (1994) argues that resilience is positively associated with social support received from one's parents, teachers and other significant others.

Grzegorzewska (2013a) lists four biological factors that may have a protective role. These are: genetic predispositions, overall physical health, temperament and sex. With regards to the latter, the author notes that the process of resilience is more likely to occur among girls than boys. The fact that they are less prone to risk factors is one of the reasons for this.

Some researchers (Yates, Egeland, \& Sroufe, 2003) treat resilience as a developmental process, which allows the child to use the available resources in a process of adaptation. Yates stresses that discussing the phenomenon of resilience requires a consideration of many elements, which is why it cannot be measured directly (Luthar \& Zelazo, in: Borucka \& Ostaszewski, 2008). However, it is possible to make inferences by analysing various indices that are considered to be measures of positive adaptation. Included among them are various spheres of a child's functioning, involving both intra- and interpersonal characteristics of an individual, their self-esteem and school achievements, satisfaction with life and quality of life, as well as the level of fulfilment of developmental tasks (Grzegorzewska, 2013b). Research from Sweden, conducted in a group of adolescents with motor disabilities, suggested that protective factors, such as social competences of an individual, good functioning within one's family and good relations with peers, foster an improvement of one's quality of life (Alriksson-Schmidt, Wallander, \& Biasini, 2007).

Resilience can also be treated as a personality feature or personal resource. Block and Block (1980) consider it as an important personality feature, which is especially crucial in the process of overcoming traumatic events, but also dealing with everyday life. It is a relatively durable disposition, determining an elastic adaptation to the constantly changing requirements of reality. This trait is most commonly referred to as mental resilience, and a set of the listed features characterises a resilient individual. Resilient individuals are self-confident, productive, value their independence, have a sense of humour and find it easy to gain other people's fondness and acceptance. They are aware of the motives for their own actions and they follow through with initiated tasks. Moreover, they are characterised by cordiality and the ability to form close relationships with others (Block \& Block, 1980).
Resiliency and social support in adolescents 
Resilience is associated with self-trust and the sense of intimacy with others. Resilient individuals are characterised by an increased openness for undertaking challenges and readiness to engage in new, sometimes unexpected situations that contribute to personal development (Uchnast, 1997, 1998). In general, resilience, treated as a personal resource, includes elastic adaptation to life's requirements, persistence in pursuing goals, increased tolerance of negative experiences, the competence of coping with difficult situations, openness to new experience and an optimistic attitude towards life (Ogińska-Bulik \& Juczyński, 2008, 2010, 2011) 1 .

The two ways of understanding resilience are not mutually exclusive; rather they complement each other. This is suggested by Waller (in: Heszen \& Sęk, 2007), who treats resilience as a dynamically changing outcome of the interaction of various forces in the context of an ecosystem, determined by multiple factors. Therefore, resilience is not only a collection of personal features, but it also stems from interactions between the features of an individual and the environment. It is a dynamic characteristic, and it depends on the life context in which it can be shaped and developed.

\section{RISK FACTORS AMONG CHILDREN IN CHILDREN'S HOMES}

A stay at a children's home is treated as a risk factor for the development of an individual, which may lead to symptoms of maladaptation and pathology. A child may need to stay in a children's home due to various reasons that might be associated with a loss of a parent or both parents, but it may also be a result of abandonment, violence, mental illnesses or alcoholism of the parents. According to the Polish Supreme Audit Office (Polish: Najwyższa Izba Kontroli, NIK) in 2011 (http://www.nik.gov.pl/plik/id,3757,vp,4791. pdf), the most common reason for putting a child in a home is the helplessness of the parents coupled with care and educational problems (32\%). Poverty is the second most common reason $(26 \%)$ and violence in the family the third (17\%). These are followed by illness $(11 \%)$, insufficient living conditions $(7 \%)$ or a parent staying abroad (7\%). Therefore, the stay of a child in a home is associated with dysfunction of the family system.

Parents' alcoholism is a particularly unfavourable situation for the child. As noted by Grzegorzewska (2013b), children from families with alcohol-related problems are in a risk group for various kinds of mental disorders, and their sense of well-being is lower than for the children in families with no symptoms of dysfunction. Poverty, which can be treated as an independent risk factor, may also lead to children's stay in the institution. Lack of financial means can hinder the quality of parental care and the support offered to the child. What is more, poverty can co-occur with depression or other mental disorders of the parents (Yates et al., 2003), which additionally increases the risk of deprivation or limiting of parental authority over children. It is worth highlighting that children and youth from families experiencing problems with poverty are more likely to engage in problematic behaviours such as drinking alcohol, recreational drug use and being aggressive or violent towards others (Buckner, MezzaCappa, \& Beardslee, 2003).

\section{PARTICIPANTS AND PROCEDURE}

Most research concentrates either on the process of resilience or its role when treated as a personal resource in different areas of an individual's functioning. There are no studies that consider both meanings of resilience, and thus indicate the role served by mental resilience treated as a personal resource of an individual, in the process of resilience. Limited data are available about the importance of social support in the process of an individual's adaptation to unfavourable life conditions.

The goal of the current study was to establish whether youths living in children's homes are affected by the phenomenon of resilience, and to verify whether, and to what extent, mental resilience (a personal resource) and social support (a social resource) correlate with this process. Perceived quality of life of at least an average level was used as an indicator of resilience. Answers to the following research questions were sought:

- What is the perceived quality of life of subjects living in children's homes, and what proportion of the subjects can be considered resilient?

- Do gender and age influence the perceived quality of life of the investigated youths?

- What are the levels of resilience and social support among the subjects?

- Is there a correlation between the levels of mental resilience as well as social support, and the perceived quality of life?

- Which of the analysed explanatory variables (mental resilience, social support) can predict the perceived quality of life, treated as an explanatory variable?

A stay in a children's home was the risk factor for the subjects of the current study. In turn, mental resilience and social support were the protective factors. It was assumed that the youths that exhibited higher levels of resilience and received more social support would report a higher perceived quality of life and thus exhibit more signs of adaptation. Eighty wards of children's homes in Lodz, Poland took part in the study ${ }^{2}$. The study was conducted with the consent of the institutions' managing directors. The participants were informed about the voluntary charac- 
ter of participation in the study and its anonymity. Results for 60 individuals with at least one biological parent were analysed: 29 boys and 31 girls aged 11-17 $(M=14.80, S D=2.00)^{3}$. Three research methods, characterised below, were used.

Subjective Quality of Life Questionnaire for Children and Adolescents (Polish: Kwestionariusz Poczucia Jakości Życia dla Dzieci i Młodzieży - KPJŻ-DiM), which is a modified version of the questionnaire for adults by Schalock and Keith, developed by Oleś (2010). Similarly to the version for adults, it consists of 40 items, each with 3 possible responses assessed on a scale from 3 to 1 . Higher scores indicate higher quality of life. The questionnaire allows one to establish the overall quality of life that relates to four spheres. First: satisfaction - regarding the overall satisfaction with life and one's life situation, material situation, relations with significant others and the position in one's family, achievements, emotions and experiences. Second: competences/productivity - regarding the satisfaction with one's own skills, abilities and performance at school, as well as the sense of self-competence and knowledge. Third: empowerment/independence, which regards the level of independence and self-sufficiency, the ability to make choices and everyday decisions. Fourth: social belonging/community integration - the sense of belonging in a group, spending free time together, participation in social life. The questionnaire is characterised by good psychometric properties, with the Cronbach $\alpha$ of .90 .

Resilience Measurement Scale (Polish: Skala do Pomiaru Prężności - SPP-18), by Ogińska-Bulik and Juczyński (2011), was developed for children and adolescents aged 12-19. The tool consists of 18 items, assessed on a 5-point scale where 0 stands for strongly disagree, 1 - somewhat disagree, 2 - neither agree nor disagree, 3 - somewhat agree, 4 - strongly agree. The higher the score, the higher the levels of resilience. The raw results are recalculated to sten scores. SPP-18 allows one to establish an overall score and scores for four factors constituting resilience. These are: optimistic attitude and energy, persistence and determination in action, sense of humour and openness to new experiences, personal competences and a tolerance for negative affect. The tool is characterised by good psychometric properties. Its Cronbach's $\alpha$ equals .82 (from .76 to .87 for the subscales). The test-retest reliability of the tool established at a 6-week time interval equals .78.

Scale of Social Support (Polish: Skala Wsparcia Społecznego), by Kmiecik-Baran, is used for measuring the level of social support received by an individual, which includes its four types: emotional, evaluative, instrumental and informational. This scale also allows one to distinguish between eight sources of support: received from parents ${ }^{4}$, siblings, other relatives, school peers, neighbourhood peers, neighbours, teachers and strangers. It consists of 16 items. The participant has to answer questions on a 4-point scale ( 0 - no, it does not apply, 1 - probably not, 2 - probably yes, 3 -yes). The reliability of the tool for different types of support assessed by Cronbach's $\alpha$ is between .56 and .79 (Kmiecik-Baran, 2000).

\section{RESULTS}

Due to the normal distribution of the analysed variables (the Kolmogorov-Smirnov test $-d=-.07, p>.200$, kurtosis $=-.27$, skewness $=-.44)$, parametric tests were used to analyse the results for quality of life, i.e. the Student $t$-test was used to assess the differences between means, Pearson's correlation coefficient was used to verify the correlations between variables, and a stepwise progressive regression analysis was used in order to establish the predictors of perceived quality of life (Table 1).

The perceived quality of life among the participants was significantly lower than in the group of healthy youths studied by Oleś $(M=94.75, S D=10.53$, $p<.001)$. This concerned especially the first two areas, that is satisfaction $(M=23.05, S D=3.62)$ and competence/productivity $(M=22.53, S D=3.96)$. However, in the remaining two areas, i.e. empowerment/ independence, as well as social belonging/community integration, the participants scored slightly higher $(M=25.56, S D=2.87$ and $M=23.60, S D=3.52$ accordingly).

Gender did not differentiate between the overall score for perceived quality of life (boys: $M=85.93$, $S D=10.08$, girls: $M=89.48, S D=9.45, t=-1.41)$. However, it differentiated between three out of four of its areas, i.e. satisfaction (boys: $M=21.41, S D=3.86$, girls: $M=19.32, S D=3.65, t=2.15, p<.050)$, empowerment $/$ independence (boys: $M=21.62, S D=3.73$, girls: $M=24.81$, $S D=3.35, t=-3.48, p<.001)$ and finally social belonging/community integration (boys: $M=21.17$, $S D=3.61$, girls: $M=23.03, S D=3.07, t=-2.15, p<.050$ ).

Age differentiates the overall score on the Subjective Quality of Life Questionnaire for Children and Adolescents scale, as well as one of its component areas. The younger participants (aged less than 16) were characterised by a lower perceived quality of life $(M=84.97, S D=10.72)$ when compared to the older participants $(M=90.57, S D=8.12, t=-2.28$, $p<.050)^{5}$. They also scored lower on empowerment/ independence (younger: $M=21.47, S D=3.90$, older: $M=25.07, S D=2.89, t=-4.05, p<.001)$.

The resilience results, measured by the SPP- 18 test, correspond to a sten score of 6 , which is an average score according to the norms (Ogińska-Bulik \& Juczyński, 2011). The obtained values - both the overall score and the scores on the subscales - are slightly higher than the results of normalisation studies, where the average result for the overall SPP-18
Resiliency and social support in adolescents 
Table 1

Means and standard deviations of the analysed variables

\begin{tabular}{lcc}
\hline Variable & $M$ & $S D$ \\
\hline Subjective quality of life - overall & 87.75 & 9.84 \\
1. Satisfaction & 20.33 & 3.87 \\
2. Competence/productivity & 22.03 & 2.43 \\
3. Empowerment/independence & 23.26 & 3.86 \\
4. Social belonging/community integration & 22.13 & 3.44 \\
\hline Resilience - overall & 48.20 & 10.97 \\
1. Optimistic attitude and energy & 13.17 & 3.66 \\
2. Persistence and determination in action & 13.28 & 3.93 \\
3. Sense of humour and openness to new experience & 11.45 & 3.01 \\
4. Personal competences and tolerance for negative affect & 10.30 & 3.15 \\
\hline Social support - overall & 221.10 & 41.17 \\
1. Informational support & 56.13 & 10.04 \\
2. Instrumental support & 50.30 & 9.77 \\
3. Evaluative support & 53.01 & 12.36 \\
4. Emotional support & 61.66 & 14.07 \\
\hline
\end{tabular}

score was $45.65(S D=11.04)$. The scores of the participating children's homes pupils on the Social Support Scale, regarding both the overall support and its separate dimensions, are at average levels, according to the norms by Kmiecik-Baran (2000).

Further analyses were conducted in order to establish a relationship between resilience as well as social support, and the perceived quality of life in the studied group of children's home wards. The obtained correlation coefficients are presented in Table 2.

The correlation coefficients presented in Table 2 suggest significant correlations, particularly between the perceived quality of life and mental resilience. Resilience was positively correlated with the overall perceived quality of life as well as with all of its dimensions. The strongest correlation was observed for the skills/competences subscale. Taking into account each of the dimensions of resilience, one can observe a stronger relationship between the perceived quality of life and an optimistic attitude and energy $(p<.001)$ than with the other dimensions. The weakest correlation was observed for personal competences and tolerance for negative affect $(p<.050)$.

Perceived quality of life in the studied group of children's home pupils was also associated with the received social support. It was positively correlated with the overall score on the Subjective Quality of Life Questionnaire for Children and Adolescents scale and its two sub-scales, i.e. empowerment/in- dependence and social belonging/community integration. In terms of the component types of support, significant correlations were observed between the perceived overall quality of life and emotional support and, to a lesser degree, evaluative support.

It was also verified whether the studied adolescents reporting high and low levels of perceived quality of life differed in terms of the analysed personal resources. The subjects were divided according to an arithmetic mean of scores obtained on the Subjective Quality of Life Questionnaire for Children and Adolescents scale. The results are presented in Table 3.

Data presented in Table 3 show that the studied youths characterised by higher levels of perceived quality of life exhibited a higher level of overall resilience and three of its dimensions, i.e. optimistic attitude towards life, persistence and determination in action, as well as sense of humour and openness to new experience. Perceived quality of life did not differentiate significantly between the levels of social support, though individuals reporting higher quality of life scored slightly higher on the social support scale.

The next step was to look for predictors of perceived quality of life and its four dimensions treated as the explained variables. The overall scores of resilience and social support were treated as explanatory variables, followed by the four features that resilience consists of, and the four kinds of support. The regression analysis is summarised in Table 4. 
Table 2

Coefficients of correlation between resilience as well as social support, and perceived quality of life in the group of children's home wards

\begin{tabular}{lccccc}
\hline Variable & $\begin{array}{c}\text { Perceived quality } \\
\text { of life }- \text { overall }\end{array}$ & 1 & 2 & 3 & 4 \\
\hline Resilience - overall & $.44^{* *}$ & $.30^{*}$ & $.45^{* * *}$ & $.29^{*}$ & $.28^{*}$ \\
1. Optimistic attitude and energy & $.41^{* *}$ & $.30^{*}$ & $.46^{* * *}$ & $.32^{* *}$ & .17 \\
$\begin{array}{l}\text { 2. Persistence and determination } \\
\text { in action }\end{array}$ & $.36^{* *}$ & .24 & $.45^{* *}$ & .20 & .22 \\
$\begin{array}{l}\text { 3. Sense of humour and openness } \\
\text { to new experience }\end{array}$ & $.34^{* *}$ & .07 & $.27^{*}$ & $.28^{*}$ & $.37^{* *}$ \\
$\begin{array}{l}\text { 4. Personal competences and } \\
\text { tolerance for negative affect }\end{array}$ & $.28^{*}$ & & & .12 & .14 \\
\hline $\begin{array}{l}\text { Social support - overall } \\
\text { 1. Informational }\end{array}$ & $.33^{* *}$ & $.33^{* *}$ & .21 & .12 & $.27^{*}$ \\
2. Instrumental & .24 & .13 & .15 & $.33^{* *}$ & .19 \\
3. Evaluative & .18 & .11 & .13 & $.32^{* *}$ & .04 \\
4. Emotional & $.27^{*}$ & .22 & .13 & $.31^{* *}$ & .22 \\
\hline
\end{tabular}

Note. ${ }^{* *} p<.001,{ }^{* *} p<.010,{ }^{*} p<.050$; Dimension 1 - satisfaction, Dimension 2 - competence/productivity, Dimension 3 - empowerment/independence, Dimension 4 - social belonging/community integration.

Table 3

Mean scores for resilience and social support in high and low perceived quality of life sub-groups

\begin{tabular}{|c|c|c|c|c|c|c|}
\hline \multirow[t]{3}{*}{ Resources } & \multicolumn{6}{|c|}{ Perceived quality of life } \\
\hline & \multicolumn{2}{|c|}{ low $(n=29)$} & \multicolumn{2}{|c|}{ high $(n=31)$} & \multirow[t]{2}{*}{$t$} & \multirow{2}{*}{$p<$} \\
\hline & $M$ & $S D$ & M & $S D$ & & \\
\hline Resilience - overall & 43.34 & 12.08 & 52.74 & 7.51 & -3.64 & .001 \\
\hline 1. Optimistic attitude and energy & 11.72 & 4.34 & 14.52 & 2.21 & -3.16 & .010 \\
\hline 2. Persistence and determination in action & 11.58 & 4.43 & 14.87 & 2.57 & -3.54 & .001 \\
\hline $\begin{array}{l}\text { 3. Sense of humour and openness } \\
\text { to new experience }\end{array}$ & 10.55 & 3.23 & 12.29 & 2.57 & -2.31 & .050 \\
\hline $\begin{array}{l}\text { 4. Personal competences and tolerance for } \\
\text { negative affect }\end{array}$ & 9.48 & 3.61 & 11.06 & 2.47 & -1.99 & n.s. \\
\hline Social support - overall & 209.21 & 48.11 & 229.68 & 31.06 & -1.99 & n.s. \\
\hline 1. Informational & 53.75 & 11.24 & 58.35 & 8.36 & -1.80 & n.s. \\
\hline 2. Instrumental & 48.10 & 11.08 & 52.35 & 8.01 & -1.71 & n.s. \\
\hline 3. Evaluative & 51.06 & 14.66 & 54.83 & 9.64 & -1.18 & n.s. \\
\hline 4. Emotional & 59.03 & 15.20 & 64.13 & 12.69 & -1.41 & n.s. \\
\hline
\end{tabular}

Both of the analysed resources were found to be significant predictors of quality of life, expressed in the overall Subjective Quality of Life Questionnaire for Children and Adolescents score. Resilience played a slightly more important role, explaining $19 \%$ of the overall perceived quality of life score, in comparison to social support, which explained $9 \%$ of the variance.

The goal of the further analyses was to look for predictors for the individual areas of quality of life. The predictive role of both of the resources was con-
Resiliency and social support in adolescents 
Table 4

Predictors of perceived quality of life in the studied group of children's home wards

\begin{tabular}{lcccccc}
\hline & $\beta$ & $\beta$ error & $B$ & $B$ error & $t$ & $p<$ \\
\hline Resilience & .34 & .11 & .30 & .10 & 2.84 & .010 \\
Social support & .32 & .11 & .07 & .02 & 2.67 & .010 \\
Constant value & & & 56.54 & 6.74 & 8.38 & .001 \\
\hline
\end{tabular}

Note. $R=.53, R^{2}=.28, \beta$ - standardised regression coefficient, $\beta$ error - standardised error estimate, $B$ - non-standardised regresNina

Ogińska-Bulik,

Magdalena

Kobylarczyk

Table 5

Dimensions of resilience and types of support as predictors of perceived quality of life in the investigated group of children's home wards

\begin{tabular}{lcccccc}
\hline & $\beta$ & $\beta$ error & $B$ & $B$ error & $t$ & $p$ \\
\hline $\begin{array}{l}\text { Dimension 1. Optimistic } \\
\text { attitude and energy }\end{array}$ & .37 & .11 & .98 & .30 & 3.27 & .001 \\
Informational support & .35 & .11 & .34 & .11 & 3.17 & .010 \\
Constant value & & & 55.26 & 6.95 & 7.94 & .001 \\
\hline
\end{tabular}

Note. $R=.54, R^{2}=.29, \beta$ - standardized regression coefficient, $\beta$ error - standardised error estimate, $B$ - non-standardised regression coefficient, $B$ error - estimate's standard error.

firmed. Social support was found to predict sense of satisfaction and perceived quality of life associated with social belonging/community integration. In the case of the former it explained $13 \%\left(\beta=.28, R^{2}=.13\right)$ and in the latter $12 \%\left(\beta=.28, R^{2}=.12\right)$ of the independent variable variance. Resilience predicted perceived quality of life associated with personal skills/ competences $\left(\beta=.39, R^{2}=.20\right.$ ), explaining $20 \%$ of the result's variance. No predictors were found for empowerment/independence.

Further analyses regarded searching for the predictors of perceived quality of life, taking into account the four factors of resilience and four types of support. They are presented in Table 5.

Two variables predicted the overall perceived quality of life: optimistic attitude and energy (the first feature of resilience), as well as informational support. Together, both variables explain $29 \%$ of the variance of the independent variable, while the resilience factor had a slightly larger influence on the prediction, responsible for $17 \%$ of the variance of the independent variable $\left(\beta=.37, R^{2}=.17\right)$. In comparison, the informational support explained $12 \%$ $\left(\beta=.35, R^{2}=.12\right)$. A more detailed analysis showed that informational support, personal competences, and tolerance for negative affect (the fourth dimension of resilience) predicted sense of satisfaction, explaining $19 \%$ of the variance of the independent variable. Informational support explained more $(\beta=.33$, $\left.R^{2}=.12\right)$ than the analysed resilience dimension $\left(\beta=.20, R^{2}=.07\right)$.
The first dimension of resilience - optimistic attitude and energy - turned out to be the only predictor of perceived quality of life associated with personal skills/competences $\left(\beta=.31, R^{2}=.21\right)$. In turn, perceived quality of life associated with empowerment/ independence could be explained by the level of the first dimension of resilience - optimistic attitude and energy - and the informational support. Together they explain $16 \%$ of the variance. This dimension of resilience played a larger part $\left(\beta=.31, R^{2}=.10\right)$, in comparison to the quoted type of support $(\beta=.38$, $\left.R^{2}=.06\right)$. The third dimension of resilience - sense of humour and openness to new experience - was found to predict social belonging/community integration, explaining $14 \%$ of variance of the independent variable $\left(\beta=.32, R^{2}=.14\right)$.

\section{DISCUSSION AND CONCLUSIONS}

The scores obtained in the Subjective Quality of Life Questionnaire for Children and Adolescents test by the pupils of children's homes proved to be lower than the results of healthy adolescents studied by Oleś (2010). Thirty-one youths, constituting $51.60 \%$ of the participants, scored average or high for the perceived quality of life. This suggests that these individuals adapted to the adverse situation of being put in a children's home. Thus, it can be said that the process of resilience occurred in these individuals. The available literature suggests that this process is relatively common. Research by Werner (in: 
Grzegorzewska, 2013b), conducted among children from a developmental adversity risk group, revealed that over $80 \%$ of the initial risk group (poverty, alcoholism, violence, instability in the family) regained balance or coped with the requirements of life (they formed stable relationships, had good jobs and satisfactory interpersonal relations, and functioned well in the civil society). The commonness of the resilience process seems to be confirmed by the results of a study by Silverman and Worden (in: Clark, Pynoos, \& Rutter, 1999), which showed that $83 \%$ of children (from a group of 125 subjects) successfully coped with a death of a parent within a period of 4 months since its occurrence.

One could therefore wonder why the process of adaptation did not occur in almost half of the pupils of children's homes who participated in the present study. It may be associated with their present situation. The participants of the current study all inhabited the institutions at the time of the study. From the perspective of youths, bereft of parental care, it is definitely an unfavourable situation. One can suppose that a study regarding perceived quality of life among adults who are ex-pupils of children's homes would give a better indication of whether they have undergone the adaptation process. It is also worth noting that the perceived quality of life is just one of the possible indicators for the assessment of the resilience process. One cannot exclude the possibility that the use of another indicator, or more indicators simultaneously, would have yielded different results. Additionally, it is worth highlighting that the lack of symptoms of adaptation in some of the participants does not necessarily mean that they exhibit strong symptoms of maladaptation.

Gender did not significantly differentiate the overall perceived quality of life; however, boys scored significantly higher in terms of satisfaction with life and girls scored significantly higher in terms of empowerment/independence as well as social belonging/community integration. This result is similar to the results obtained by Oleś (2010), where perceived quality of life was higher in these two areas among girls. Age influenced the perceived quality of life of the currently studied youths. Older youths exhibited higher overall perceived quality of life, and scored higher on the empowerment/independence scale. Age was also shown to differentiate the perceived quality of life in a previous study by Oleś (2010); however, the younger children (aged 11-13) scored higher in the Subjective Quality of Life Questionnaire for Children and Adolescents scale in comparison to the older children and adolescents (aged 14-16 and 17-18).

The current results suggest a positive correlation between mental resilience, understood as a personal resource, as well as support (social resource), and the perceived quality of life of the participants - wards of children's homes. The strongest correlations were observed for resilience, which was shown to be positively correlated with all of the analysed areas of quality of life. The overall score for social support was significantly correlated with the overall score for the perceived quality of life and only one of its areas, i.e. empowerment/independence. A stronger relationship between resilience and perceived quality of life was confirmed by the regression analysis. It showed that resilience explains twice as much of the variance in the overall quality of life (19\%) in comparison to social support (9\%). Most of all, whereas resilience allowed prediction of the perceived quality of life regarding personal skills/competences, social support predicted sense of satisfaction and quality of life associated with social belonging/community integration.

The conducted regression analysis, taking into account all of the dimensions of resilience and types of support, gives a more complex picture of the correlations between resilience as well as support, and perceived quality of life. Optimistic attitude and energy (the first dimension of resilience) and informational support were found to predict overall perceived quality of life. Three of the dimensions of resilience had a predictive role for the distinguished features of quality of life. Optimistic attitude towards life and energy (dimension 1) was the only dimension of resilience that predicted perceived quality of life associated with personal skills/competences. Moreover, along with the informational support, it allowed prediction of satisfaction with one's empowerment/ independence. Personal competences and tolerance for negative affect (dimension 4), along with informational support, turned out to predict sense of satisfaction. In turn, the third resilience factor, that is sense of humour and openness to new experience, predicted the perceived quality of life associated with social belonging/community integration.

A positive relationship between mental resilience (measured by SPP-18) and quality of life (assessed using Kidscreen) was established in a group of adolescents in a study by Ogińska-Bulik (2010). The second factor of resilience (persistence and determination in action) played a particularly important role for the quality of life, though optimistic attitude towards life and energy (dimension 1) as well as personal competences and tolerance for negative affect (dimension 4) also played a role.

Research by Grzegorzewska (2013a, 2013c) provided data suggesting that resilience is a predictor of positive adaptation among children of alcoholic parents. A positive correlation between resilience and satisfaction with life was also noted among adults, e.g. in a group of German women (Beutel, Glaesmer, Decker, Fischbeck, \& Brahler, 2009), among students (Chung, 2008), as well as individuals who had undergone rehabilitation due to spine injuries (White,
Resiliency and social support in adolescents 
Driver, \& Warren, 2010) and a group of widows (Rossi, Bisconti, Bergeman, 2007). Resilience was also positively correlated with satisfaction with life in a group of alcohol-dependent men (Ogińska-Bulik, 2014). These quoted results confirm the importance of resilience in the process of development of the sense of quality of life, independent of age.

The current results also confirmed the important role of social support in the process of development of the sense of quality of life in a group of adolescents. These results are largely consistent with those obtained by Oleś (2010), which suggested that social support was one of the predictors of quality of life among adolescents aged between 17-18. However, it is worth noting that there have been other studies that did not confirm the relationship between social support and resilience (Buckner et al., 2003).

The weaker correlations between social support and perceived quality of life among the pupils of children's homes may be caused by the limited role of some of the sources of support (particularly the support coming from an individual's parents), since the current study analysed the support received from carers in the institution, not parents. Moreover, staying in a children's home may be additionally associated with lower levels of support from siblings or other relatives.

Summing up, resilience and social support were found to be important factors protecting the studied youths exposed to negative life experiences and promoting the resilience process. However, one should remember that it is a complex process, based on multiple indices and extended in time, while protective factors, as stressed by Grzegorzewska (2013b), allow one to predict positive developmental outcomes in about $50-80 \%$ of children from the risk group.

It is also important to highlight the limitations of the current study. It was a cross-sectional study, which does not allow one to assess causal links. The number of participants was relatively small. The reasons for their placement in children's homes were not analysed. Resilience was assessed based on one indicator only. Despite these limitations, the present results broaden the knowledge about the phenomenon of resilience, pointing particularly towards the importance of personal resources of an individual. They are in line with positive psychology, as the concept of resilience, despite applying to those exposed to prolonged stress, focuses on resources rather than deficits. The current results can be useful in practice, especially with regards to introducing preventive and interventional measures among adolescents in the risk group. They indicate the need to develop resilience associated with successful coping with adversities. It seems worthwhile to continue research on the process of resilience, taking into account the ways to deal with adversities, as well as other personal resources of an individual.

\section{ENDNOTES}

1 For a more detailed discussion of the term resilience see Junik, 2011; Nadolska \& Sęk, 2007, Ogińska-Bulik \& Juczyński, 2008, 2010, 2011; Ostrowski, 2013.

2 Study by an MA seminar participant, Justyna Mańka.

3 Results of 20 wards were omitted in the analysis, as their questionnaires were incompletely filled in.

4 In the case of the studied youths, this was the support of the institution's caregivers. Differentiation between sources of support was not included in the analysis.

5 The criterion for division into younger and older was the mean age of the study group of adolescents.

\section{REFERENCES}

Ahern, N., Kiehl, E., Lou Sole, M., \& Byers, J. (2006). A review of instruments measuring resilience. Issues in Comprehensive Pediatric Nursing, 29, 103125.

Alriksson-Schmidt, A., Wallander, J., \& Biasini, F. (2007). Quality of life and resilience in adolescents with a mobility disability. Journal of Pediatric Psychology, 32, 370-379.

Beutel, M., Glaesmer, H., Decker, O., Fischbeck, S., \& Brahler, E. (2009). Life satisfaction, distress, and resiliency across the life span of women. Menopause, 16, 1132-1138.

Block, J. H., \& Block, J. (1980). The role of ego-control and ego-resiliency in the origination of behavior. In: W. A. Collings (ed.), The Minnesota Symposia on Child Psychology (pp. 39-101). NJ: Hillsdale, ErIbaum.

Borucka, A., \& Ostaszewski, K. (2008). Koncepcja resilience. Kluczowe pojęcia i wybrane zagadnienia [The concept of resilience. Key terms and selected issues]. Medycyna Wieku Rozwojowego, 12, 587-597.

Buckner, J., MezzaCappa, E., \& Beardslee, W. (2003). Characteristics of resilient youths living in poverty: The role of self-regulatory process. Development and Psychopathology, 15, 139-162.

Chung, H. (2008). Resiliency and character strengths among college students. www.gradworks.uni.com /33/07/3307360.html (last accessed: 31.08.2010).

Clark, D., Pynoos, R., \& Goebel, A. (1999). Mechanisms and processes of adolescent bereavement. In: R. Haggerty, L. Sherrod, N. Garmezy, \& M. Rutter (eds.), Stress, risk and resilience in children and adolescents (pp. 100-146). United Kingdom: Cambridge University Press.

Ferguson, D. M., \& Horwood L. J. (2003). Resilience to childhood adversity. Results of 21 year study. In: S. Luthar (ed.), Resilience and vulnerability: Adaptation in the context of childhood adversities 
(pp. 130-155). Cambridge: Cambridge University Press.

Garmezy, N. (1991). Resiliency and vulnerability to adverse developmental outcome with poverty. American Behavioral Sciences, 34, 416-430.

Grzegorzewska, I. (2013a). Odporność psychiczna dzieci alkoholików [Mental resilience among the children of alcoholics]. Warszawa: Wydawnictwo Naukowe Scholar.

Grzegorzewska, I. (2013b). Aktualny stan badań nad zjawiskiem odporności psychicznej w populacji dzieci alkoholików [The current state of research on the phenomenon of mental resilience in the population of children with alcoholic parents]. Polskie Forum Psychologiczne, 18, 385-399.

Grzegorzewska, I. (2013c). Individual predispositions and positive adaptation of children of alcoholics. Current Issues in Personality Psychology, 1, 11-25.

Heszen, I., \& Sęk, H. (2007). Psychologia zdrowia [Psychology of Health]. Warszawa: PWN.

Junik, W. (2011). Zjawisko rezyliencji - wybrane problemy metodologiczne [The phenomenon of resilience - selected methodological problems]. In: W. Junik (ed.), Resilience. Teoria. Badania. Praktyka [Resilience. Theory. Research. Practice] (pp. 47-65). Warszawa: Wydawnictwo Parpamedia.

Kmiecik-Baran, K. (2000). Narzędzia do rozpoznawania zagrożeń społecznych w szkole [Tools for recognising social risks in a school environment]. In: Młodzież i przemoc (tom 4) [Youth and violence] (vol. 4). Gdańsk: Wydawnictwo Przegląd Oświatowy.

Luthar, S., Cicchetti, D., \& Becker, B. (2000). The construct of resilience: critical evaluation and guidelines for future work. Child Development, 71, 543562.

Masten, A. S., \& Coatsworth, D. (1995). Competence, resilience and psychopathology. In: D. Cicchetti, D. J. Cohen (eds.), Developmental Psychology: Risk, disorder and adaptation (vol. 2, pp. 715-752). New York: Wiley.

Masten, A. S., \& Obradovic, J. (2008). Disaster preparation and recovery: Lessons from research on resilience in human development. Ecology and Society, 13, 9.

Nadolska, K., \& Sęk, H. (2007). Społeczny kontekst odkrywania wiedzy o zasobach odpornościowych, czyli czym jest resilience i jak ono funkcjonuje [The social context of gathering the knowledge about immunity resources - what is resilience and how does it work]. In: Ł. Kaczmarek, \& A. Słysz (eds.), Bliżej serca - zdrowie i emocje [Closer to the heart - health and emotions] (pp. 13-37). Poznań: Wydawnictwo UAM

NIK. http://www.nik.gov.pl/plik/id,3757,vp,4791.pdf. Ogińska-Bulik, N. (2010). Prężność a jakość życia mtodzieży [Resilience and the quality of life of adolescents]. Psychologia Jakości Życia, 1, 233-247.
Ogińska-Bulik, N. (2014). Prężność a zadowolenie z życia osób uzależnionych od alkoholu [Resilience and satisfaction with life of alcohol-dependednt individuals]. Alkoholizm i Narkomania, 27, 319-324.

Ogińska-Bulik, N., \& Juczyński, Z. (2010). Osobowość, stres a zdrowie [Personality, stress and health] $\left(2^{\text {nd }}\right.$ ed.). Warszawa: Wydawnictwo Difin.

Ogińska-Bulik, N., \& Juczyński, Z. (2008). Skala pomiaru prężności - SPP-25 [Resilience measuring scale - SPP-25]. Nowiny Psychologiczne, 3, 39-56.

Ogińska-Bulik N., \& Juczyński, Z. (2011). Prężność u dzieci i młodzieży: charakterystyka i pomiar polska skala SPP-18 [Resilience among children and adolescents: characteristics and measurement - Polish scale SPP-18]. Polskie Forum Psychologiczne, 16, 7-28.

Oleś, M. (2010). Jakość życia mtodzieży w zdrowiu $i$ chorobie [Quality of Life in Health and IIIness]. Lublin: Wydawnictwo KUL.

Ostaszewski, K. (2005). Druga strona ryzyka [The other side of risk]. Remedium, 2, 1-3.

Ostrowski, T. M. (2013). Resilience in the light of research and theoretical reflection. In: T. M. Ostrowski, \& I. Sikorska (eds.). Health and resilience (pp. 13-23). Kraków: Wydawnictwo UJ.

Rossi, N., Bisconti, T., \& Bergeman, C. S. (2007). The role of dispositional resilience in regaining life satisfaction after the loss of spouse. Death Studies, 31, 863-883.

Uchnast, Z. (1997). Prężność osobowa; empiryczna typologia i metoda pomiaru [Personal resilience; empirical typology and a method of measurement]. Roczniki Filozoficzne, 4, 27-49.

Uchnast, Z. (1998). Prężność osobowa a egzystencjalne wymiary wartościowania [Mental resilience and existential dimensions of valuation]. Roczniki Psychologiczne, 1, 7-27.

White, B., Driver, S., \& Warren, P. M. (2010). Resilience and indicators of adjustment during rehabilitation from a spinal cord injury. Rehabilitation Psychology, 55, 23-32.

Winfield, L. F. (1994). Developing Resilience in Urban Youth. NCREL: University of Southern California.

Yates, T., Egeland, B., \& Sroufe, A. (2003). Rethinking resilience. A developmental process perspective. In: S. Luthar (ed.), Resilience and vulnerability: Adaptation in the context of childhood adversities (pp. 243-259). Cambridge: Cambridge University Press.
Resiliency and social support in adolescents 